\title{
"E de dentro do circo saiu um passarhomem, metade homem e metade pássaro": as culturas infantis no jardim de infância
}

\author{
"Y del circo salió um pájarhombre, mitad hombre y mitad pájaro": \\ culturas infantiles em el jardín de infancia
}

\section{“Y del circo salió um pájarhombre, mitad hombre y mitad pájaro": culturas infantiles em el jardín de infancia}

Maria Manuela de Sampaio Pinto Silva!

http://orcid.org/0000-0002-1294-3597

Resumo: Este trabalho foca as culturas infantis e sua articulação com o direito de crianças cidadãos, a partir de contributos socioantropológicos e da psicologia cultural. Usando uma narrativa interpretativa na perspectiva etnográfica, circunscrevemos o estudo de caso a um jardim de infância, onde, de modo holístico e pelo reconhecimento dos artefatos criados pelas crianças como reveladores de culturas infantis, escrutinamos modos e oportunidades das crianças serem atores sociais e participarem na coconstrução do seu currículo. Recorrendo a metodologias visuais e de análise de conteúdo, debruçamo-nos sobre as interações e produções das crianças, em diversos formatos e suportes, resultado da sua atividade autônoma, a pares ou de grupo, num jardim de infância da rede pública. Dos projetos das crianças se infere conhecimento sobre a infância e sobre os processos de construção das culturas infantis.

Palavras-chave: Infância. Culturas Infantis. Projetos de Crianças.

Abstract: This paper focuses on children's cultures and their articulation with the right of citizen children, based on socio-anthropological and cultural psychology contributions. The methodology includes an interpretative narrative from an ethnographic perspective and considers a particular kindergarten as its study case. Through a holistic approach, the investigation considers the ways and opportunities children can be social actors and act in the co-construction of their curriculum. Using visual methodologies and content analysis, the study focuses on children's interactions and productions, in different formats and supports, result of their autonomous activities, in pair or groupwork activities in a public kindergarten. It was observed that children's projects lead to knowledge about childhood and the construction processes of children's cultures.

Keywords: Childhood. Children's Cultures. Children's Projects.

Resumen: Este trabajo se centra en las culturas infantiles y su articulación con el derecho de los niños ciudadanos, a partir de aportes socioantropológicos y de la psicología cultural. Utilizando una narrativa interpretativa desde la perspectiva etnográfica, el estudio de caso se circunscribe a un jardín de infantes, donde, de manera holística y a través del reconocimiento de los artefactos creados por los niños como reveladores de

\footnotetext{
' Ph.D. em Estudos da Criança, na área da Sociologia da Infância, trabalha diretamente com crianças pequenas - de 3 a 6 anos - desde 1982. Atua no Agrupamento de Escolas Amado de Souza Cardoso. E-mail: mansampaio@gmail.com
}

Olhar de professor, Ponta Grossa, v. 24, p. I-26, e-17619.072, 2021.

Disponível em <https://revistas2.uepg.br/index.php/olhardeprofessor> 
"E de dentro do circo saiu um passarhomem, metade homem e metade pássaro": as culturas infantis...

las culturas infantiles, indagamos formas y oportunidades de los niños para ser actores sociales y participar en la co-construcción de su plan de estudios. Mediante metodologías visuales y análisis de contenido, nos enfocamos en las interacciones y producciones de los niños, en diferentes formatos y soportes, como resultado de su actividad autónoma, en parejas o en grupos, en un jardín de infancia de gestión pública. De los proyectos de los niños se infiere conocimiento sobre las infancias y sobre los procesos de construcción de las culturas infantiles.

Palabras clave: Infancia. Culturas infantiles. Proyectos de niños.

\section{Introdução}

São as crianças que nos interpelam, através das suas interações e das suas produções culturais. É pela implicação ativa das crianças, pelo respeito pelos seus direitos, pelo reconhecimento de que são coconstrutoras do conhecimento científico da investigadora é que pretendemos narrar como as crianças partilham saberes e resolvem problemas, criam, inventam, interpretam, aprendem com os pares, recodificam as culturas que as circundam e mostram-nos sem preconceitos. Fazemo-lo procurando as diferenças e o que têm em comum, tentando não estabelecer relações de mérito entre umas e outras qualidades, mas entender a sua dialogicidade fora de um projeto normativo adultocêntrico para a infância.

As orientações metodológicas que desenvolvemos, sugeridas pelo conteúdo e pelo contexto da investigação, pretendem dignificar o pressuposto de que as crianças são sujeitos produtores de cultura, reafirmando-se nas relações entre os parceiros - investigadora e crianças - a confiança, a disponibilidade, o diálogo, a opinião divergente, a curiosidade, a emergência de novos saberes. $O$ facto de estarmos imersas no mesmo contexto, prolongadamente, traz-nos a vantagem da segurança dos afetos, permite uma observação contínua, dialogar muito, fazer propostas e aderir a desafios das crianças, acompanhar todos os processos relativos ao desenvolvimento dos projetos, registar de múltiplas formas as situações que nos interessam como (arte)factos empíricos, para compreendermos o real.

\section{Objetivo}

Assim, optamos por fazer uma incidência sobre os projetos de pares desenvolvidos pelas crianças no contexto de jardim de infância em que prestamos serviço docente como educadora/investigadora, porque sempre nos causaram espanto os percursos por onde nos levaram, no desenvolvimento dos projetos decorrentes do seus interesses, com o objetivo de compreender as crianças e as culturas infantis a partir de si próprias e dos artefatos de cultura autorais que produzem no jardim de infância, para melhorar o seu atendimento institucional. 


\section{Participação das crianças. Olhares sociopedagógicos cruzados sobre a infância}

A imagem da realidade, captada a partir da observação das produções das crianças, não cabe tanto na especificidade geracional da infância (QVORTRUP, 200I) mas, se quisermos escrutinar a ocorrência da participação (CORSARO, 20I I), visualizamos sem dificuldade o ofício de criança-aluno (SARMENTO, 20I la; SACRISTÁN, 2006). O jardim de infância que pressupõe a organização de todo o seu quotidiano - tempo, espaço, instrumentos de regulação e avaliação - dinamizado por processos de cooperação, evidencia a inerência da participação de todos, logo das crianças também, numa lógica de aprendizagens com sentido.

O direito à participação, embora enunciável como tal, não se concretiza num diploma legal nem esclarece quanto ao tipo de participação que as crianças podem efetivar. Fernandes \& Tomás (2009) sistematizam o conceito de participação no contexto educativo, segundo pressupostos de teor: i) epistemológico - que olham o grupo social das crianças a partir de enfoques interdisciplinares, na esteira de Prout (2010), indo além da análise dicotómica biológico vs social, natureza vs cultura e adulto vs criança; ii) sociopolítico - que consideram a criança sujeito de direitos e a infância como um grupo geracional onde as crianças são atores sociais, numa lógica de relações horizontais efetivamente participativas e emancipatórias; iii) pedagógico - onde a reflexividade da ação/praxis confere às crianças os direitos de ser competente, com voz, interventivo na organização e condução do processo educativo que lhe diz respeito.

Ainda que longe dos objetivos e rotinas da escolarização, o jardim de infância, contudo, não é alheio aos fins pedagógicos do desenvolvimento integral das crianças. Os processos que definem o aluno e o distanciam da criança têm importância relevante.

Se quisermos olhar, no jardim de infância, a infância como um paradigma social, onde as crianças existem independentemente de serem aprendentes (PROUT; JAMES 1990), o foco está no ser criança, no presente, antes daquele em que se vai tornar, contrastando com o pensamento dominante, como afirma Gunilla Halldén: "Em contraste com este quadro dominante, os académicos ligados aos novos estudos sociais da infância lançaram a ideia de que as crianças estavam a ser vistas como já sendo e não a tornar-se em" (HALLDÉN, 2005: 4).

Ora, esta outra conceção de infância não reduz talento ao acompanhamento das crianças que frequentam os jardins de infância onde se desenvolve uma gramática pedagógica, 
"E de dentro do circo saiu um passarhomem, metade homem e metade pássaro": as culturas infantis...

quanto ao respeito pelos seus direitos, quando ouve as crianças no desenvolvimento de um currículo compartilhado e socialmente legitimado por elas, e, ainda, quando constroem culturas de pares, identificadas, em outros, por Prout e James (1990) e Alenen (1990), para um profundo conhecimento da infância.

A linguagem pedagógica será um contributo para o entendimento da criança cidadã que se encontra logo nos primeiros momentos da rotina diária do jardim de infância, onde as crianças dizem, contam o que lhes é mais significativo, em interação com os adultos e pares, num registro solto de acolhimento e inclusão necessários, no exercício de uma cidadania restrita, como sugerem Tisdall et al. (2006) e a partir do que estabelecem os seus projetos de interesse, diários, povoados das ideias dos seus universos culturais, livres da imposição de um capital cultural escolarizante, contrário às suas lógicas. O modo como depois os leva à prática será apresentado, adiante, sob a forma de projetos desenvolvidos no contexto do jardim de infância.

\section{Contributos socioantropológicos, psicológicos e pedagógicos para a conceitualização das culturas infantis}

Da provocação espoletada pela interação dialógica entre as práticas das crianças, em contexto educacional, e o olhar subjetivo da educadora/investigadora interessada nas culturas infantis, à luz da sociologia da infância, surge a questão que pretendemos analisar sob uma orientação etnográfica:

De que falamos quando evocamos o conceito de culturas infantis no jardim de infância?

Sendo o jardim de infância uma instituição que é parte integrante do sistema educativo, a ele se referem, comumente, as crianças, os pais e outros, como "escola". Então, por coerência com este tipo de instituição, também é vulgar associar-se-lhe um modelo de organização pedagógica tendencialmente cognitivista, desde logo pela vinculação aos documentos orientadores do sistema e de monitorização e avaliação das aprendizagens das crianças. A vida das crianças nesta "escola" - lugar legitimado para a transmissão de cultura -, poderá ser, de modo desacautelado, considerada uma das fases de transição para a vida adulta e para a sociedade e não ter em conta a especificidade da infância.

Contra este pensamento homogeneizador da cultura escolar, damos conta de movimentos de pedagogos e de sociólogos, questionando, por um lado, as formas de construção do conhecimento e, por outro, o pleno exercício da cidadania por direito próprio, admitindo que as crianças se desenvolvem nas interações culturais e sociais, nos contextos e espaços que habitam, que são "[...] membros da sociedade, atores sociais e agentes de cultura" (SARMENTO, 20I3, p. 20). E conseguimos discernir, nos seus modos de participação no jardim de infância, transformações autorais da cultura, 
tanto sozinhas, na apropriação discursiva e dos materiais que usam, como nas relações entre pares, percebendo-se também reinterpretações coletivas das culturas (da família, dos vizinhos, dos amigos, dos media, global) que influenciam os tipos de participação.

No jardim de infância, perscrutamos a participação das crianças em vários momentos informais, lúdicos, de aprendizagem autônoma ou compartilhada pelo adulto, de interação com pares, de planeamento, sem orientações dos adultos ou em resultado de propostas do adulto, dentro da sala, no polivalente da instituição, no recreio, no meio próximo do jardim de infância. E resultaram projetos autorais das crianças que lhes atribuíram significados que vão além do que pensávamos saber sobre elas, crianças, e nos revelam as suas competências de interpretação da cultura e das respostas sociais, constituindo-se uma mais valia na nossa investigação. Concordamos com os autores quando dizem que:

A Sociologia da Infância, ao assumir que as crianças são atores sociais plenos, competentes na formulação de interpretações sobre os seus mundos de vida e reveladores das realidades sociais onde se inserem, considera as metodologias participativas com crianças como um recurso metodológico importante, no sentido de atribuir aos mais jovens o estatuto de sujeitos de conhecimento, e não de simples objecto, instituindo formas colaborativas de construção do conhecimento nas ciências sociais que se articulam com modos de produção do saber empenhadas na transformação social e na extensão dos direitos sociais (SOARES; SARMENTO; TOMÁS, 2005, p. 54).

Numa perspectiva sociocultural da aprendizagem, a ação das crianças, as suas interações e participação em atividades conjuntas introdu-las nos modos culturais de construção do conhecimento, bem como nos conhecimentos acumulados ao longo da história. A aprendizagem, intrínseca ao desenvolvimento, acontece por via das interações sociais que levam a um processo analítico de significações novas e de mudanças nos tipos de participação das crianças.

No jardim de infância, onde as crianças se assumem como crianças, onde se sujeitam a determinadas orientações curriculares, como alunas, onde estão porque os pais decidiram assim, porque são filhas, acontecem situações inesperadas e surpreendentes ou, no mínimo, não planeadas, de que só elas são autoras, quando têm oportunidade de circular pelos espaços, de se expressarem, de experimentarem, de se relacionarem de modo autônomo com as pessoas e com os materiais. Das interações surgem novas atividades, vocabulário ainda não ouvido, adaptações circunstanciais que resultam das combinações de imensas variáveis que as crianças usam como recurso e como produto. Respondem acauteladamente às suas necessidades, tendo sempre presente que não estão sozinhas.

O conceito de culturas infantis, assim pensado num campo caleidoscópico - criança-sujeito de direitos, criança-ator, criança-cidadão e criança produtora de cultura - reconhece que o debate não se situa no facto das crianças produzirem significações autônomas, mas em saber se essas significações se estruturam e consolidam em sistemas simbólicos padronizados, ainda que dinâmicos e heterogéneos 
"E de dentro do circo saiu um passarhomem, metade homem e metade pássaro": as culturas infantis...

(SARMENTO, 2004) e que um outro olhar implicará a sua aceitação como culturas infantis num contexto e num quotidiano.

A reflexão sobre o processo etnográfico ocorrido, ao descrever a densidade dos significados das práticas sociais das crianças, é testemunhado por imagens (fotografias) e produções culturais que elas foram desenvolvendo como sujeitos e autores, como que num recurso comum de afetos e memórias. Ela é também um meio de chegar mais perto das crianças.

O trabalho empírico de análise e interpretação da realidade e da sua projeção simbólica (nas fotografias e nos artefatos) leva-nos a escrutinar redes de significações culturais próprias, na complexidade que é a criança: criança (com direitos que assume dentro da instituição), aluna (que é sujeita a orientações curriculares ditadas pelas políticas educativas, logo pela "escola" que frequentam e, enquanto filha, que opta por realizar determinadas atividades curriculares para satisfação dos pais, porque tem a percepção nítida da oportunidade, contrariando por vezes a sua própria vontade) e ator que reproduz, mas de forma autoral e interpretada, a cultura.

A criança é um ser que constrói a sua identidade, em relação. Esta é uma afirmação que podemos fazer a partir dos trabalhos esmiuçados sobre a infância e a cultura, que nos levaram a perceber um feixe de conceitualizações emanadas a partir desse bloco emissor - infância-cultura - e que desenhamos assim:

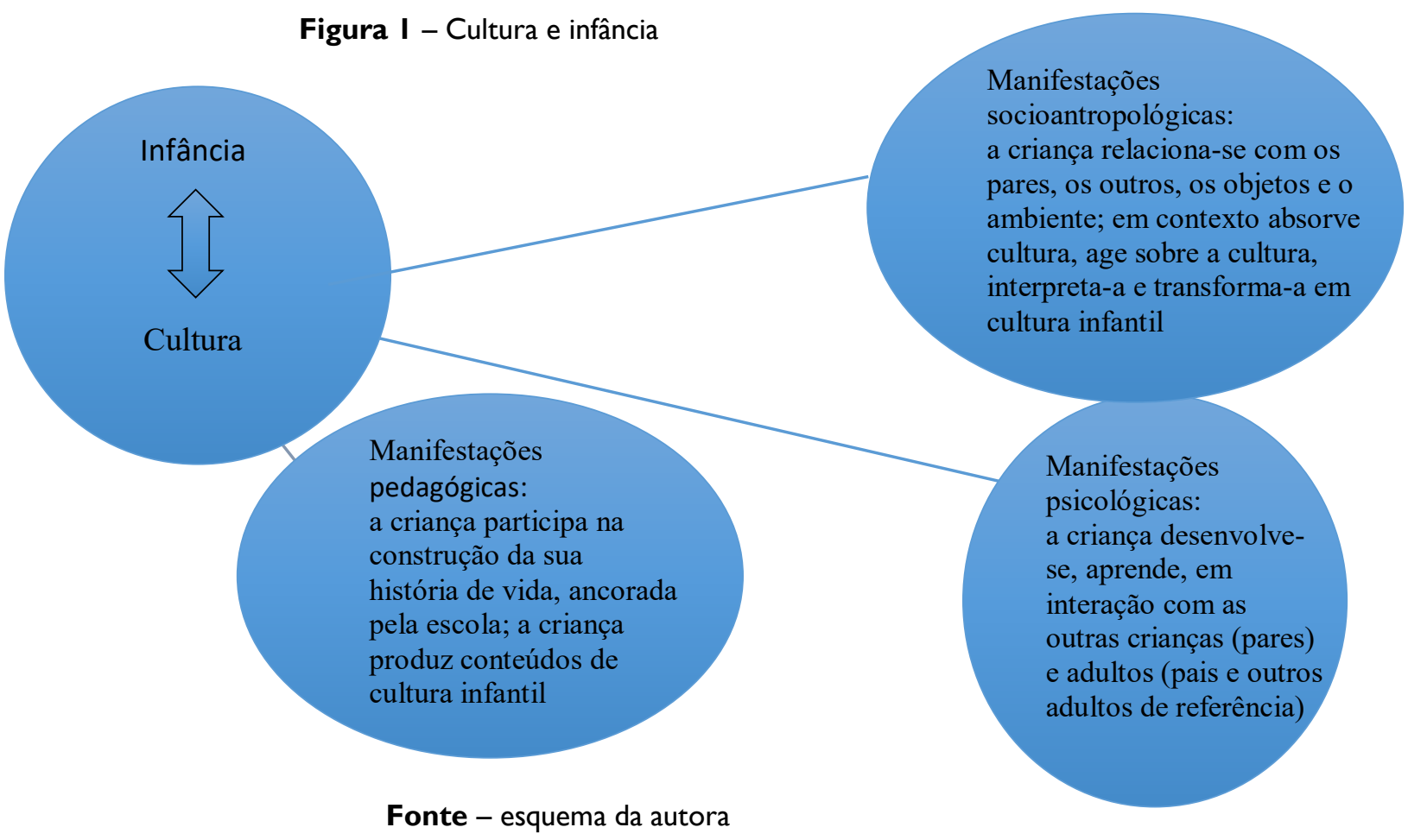

Olhar de professor, Ponta Grossa, v. 24, p. I-26, e-17619.072, 2021.

Disponível em <https://revistas2.uepg.br/index.php/olhardeprofessor> 
Decorrente da atividade numa sala de jardim de infância, de idades compreendidas entre os três e os 5 anos, damos conta de como as crianças contribuem para o processo educativo, ao conduzirem-nos pelos meandros dos seus interesses, quando queremos compreender como gerem as propostas pedagógicas, ressignificando a nossa ação educativa.

As produções das crianças, que temos para apresentar adiante, são registros de como se relacionam com os outros, com os espaços, com a cultura que apreendem e transformam, no tempo de frequência numa instituição escolar.

Numa escola de encontros - crianças e adultos, cultura instituinte e cultura construída in loco - percebemos como as crianças crescem pelo que produzem em parcerias e envolvemo-nos em compromisso com elas, ao ouvir, compreender, divergir, dialogar, traduzir, formular novos conhecimentos, como admite Barbosa (2007) numa linguagem da escola que, juntas, construímos.

A sociologia da infância tem um papel fundamental no alargamento da nossa visão pedagógica em relação às crianças, em muitos aspetos e, desde logo, quando permite identificar a contracorrente autoral das crianças numa socialização coletiva, com e entre os outros, por oposição a uma socialização individual fomentada por todo o ambiente social, económico, político, de lugar, que envolve as crianças atualmente (SARMENTO, 20I3).

\section{Os projetos das crianças}

\section{I "A toupeira"}

\section{I.I Vídeo de animação}

O vídeo de animação teve início com o conto de uma história editada em livro, disponível na biblioteca do jardim de infância, em momento da rotina semanal estipulado para a dinamização dos livros. A trama fez sucesso junto das crianças, pelas suas manifestações de interesse reiterado em momentos posteriores e espicaçou-lhes a imaginação. As personagens eram animais. Propusemos ao grupo a sua representação gráfica, o que de imediato foi aceite pela maioria. $O$ grupo das crianças mais velhas (de 5 anos), mas também outras de 4 anos, assumiram as personagens que desenharam com o material disponível; as mais novas (de 3 anos) explorando as cores dos lápis, sobre papel de gramagem alta e um pouco texturado, ilustraram o que vieram a ser os cenários. Depois da primeira manifestação de consentimento à proposta, quando iniciavam a execução, surgiram algumas dificuldades na ilustração; como é recorrente nestas situações, procuram-se os recursos que podem ajudar: vai-se aos livros ou à internet e encontram-se soluções à medida, isto é, observa-se como outros desenharam sobre o que nos interessa e usamos como modelo. Algumas crianças usaram apenas a sua imaginação 
"E de dentro do circo saiu um passarhomem, metade homem e metade pássaro": as culturas infantis...

e conhecimento para a representação; outras deitaram mão aos recursos disponíveis como suporte ao seu projeto.

A partir das ilustrações, contratualizamos com as crianças passar as imagens para animação vídeo, com os sons das suas próprias vozes - recorrendo a técnicas aprendidas, por nós, no âmbito da formação contínua de professores.

Usamos para o efeito o programa de edição vídeo Camtasia. Para tratamento das fotografias dos desenhos das crianças, o programa Photoshop. Para gravação áudio, um audiogravador vulgar. $O$ "estúdio" de gravação foi a biblioteca do Jl por ser um espaço mais resguardado dos ruídos do meio ambiente, e nos dirigimos em três momentos distintos, por necessidades de regravação. Aí também selecionamos, de entre as várias possibilidades que ouvimos, a música de fundo: o excerto Primavera, da obra Quatro Estações, de Antonio Vivaldi.

O processo de execução do vídeo foi sendo monitorizado em reuniões de grupo. Depois de desenhadas as personagens, foi preciso desenhar mais alguns elementos também importantes no guião. As crianças sempre respondiam com entusiasmo a essas solicitações.

Numa atitude recorrente de cruzamento da cultura escolar com os modos culturais infantis, as crianças organizaram-se pela quantidade de texto dito pelos animais, levaram os excertos para casa, para fazerem o treino da oralidade em interação com a família e fixaram as falas rapidamente. Passamos à gravação áudio. E, apesar de não estar implicada a totalidade do grupo, no projeto, todas as crianças estavam de algum modo imbricadas nele, sendo comum ouvi-las dizer as falas das personagens enquanto desenvolviam as suas atividades na sala.

Em modo partilha, seguindo os trâmites habituais de dar sentido às aprendizagens comunicando para os outros, as crianças quiseram apresentar o resultado às famílias. Concretizou-se o filme, que tão logo que ficou pronto foi imediatamente difundido e, na festa de final de ano, as crianças apresentaram uma dramatização da história, para a qual também construíram os adereços. É possível visualizar o vídeo no canal Youtube, no endereço: https://youtu.be/hHa5zCaya98.

\section{I.2 As ilustrações das criança}

Des. I - A toupeira

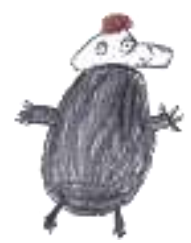

Autora - Leonor
Des. 2 - A pomba

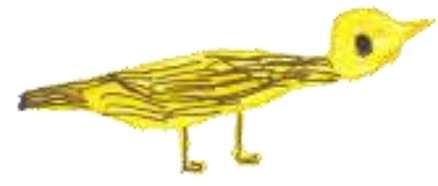

Autor - Pedro
Des. 3 - O cavalo

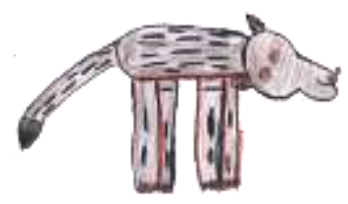

Autor - Pedro M.

Olhar de professor, Ponta Grossa, v. 24, p. I-26, e-17619.072, 2021.

Disponível em <https://revistas2.uepg.br/index.php/olhardeprofessor> 
Des. 4 - A lebre

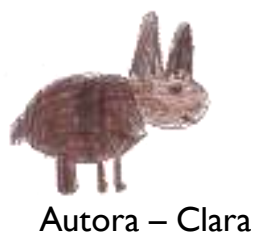

Des. 7 - O porco

Bernardo

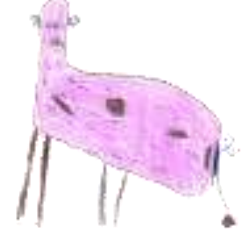

Autor - Victor
Des. 5 - A cabra

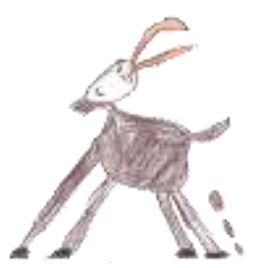

Autora - Rita

Des. 8 - As moscas

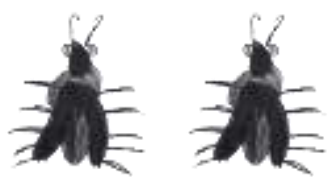

Autores - Rita e Pedro
Des. 6 - A vaca

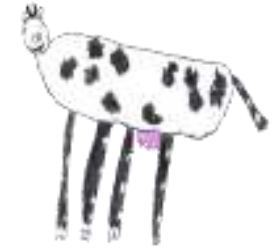

Autora - Mariana

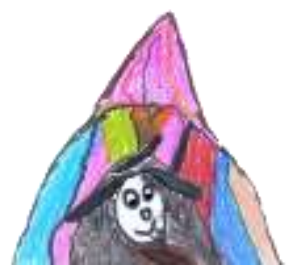

Autores - Vasco e Clara

Em todos os desenhos, se percebe a semelhança com o real e o recurso a material de investigação - as crianças procuraram documentar-se nos livros disponíveis na biblioteca do jardim de infância, sobre as características dos animais que queriam desenhar. Podemos considerar por isso que estavam a servir-se da cultura global. Ao mesmo tempo, é visível que os materiais que usaram nas representações são comuns no jardim de infância, numa atitude do cotidiano que poderemos chamar de escolar. Vemos ainda que há projetos de pares. Mas a tônica deste conjunto de conteúdos, inserimola na cultura de criança: as cores usadas, os pormenores ficcionais nas personagens que também são reais, a técnica de representação de todas as partes dos animais no plano, são inequívocas de uma ludicidade e fantasia do real presentes.

Ouvir a voz das crianças, no sentido em que se lhes atribui um papel social ativo, assume, neste projeto, uma dualidade da expressão que se estabelece entre o escutar literalmente as falas das crianças e ver os seus desenhos que animam a composição final. Porque ouvir a voz é "[...] mais do que a expressão literal de um ato de auscultação verbal [...], uma metonímia que remete para um sentido mais geral de comunicação dialógica com as crianças, colhendo as suas diversificadas formas de expressão" (SARMENTO, 20I I: 28).

Aqui se completa o sentido da comunicação verbal com as imagens evocativas de uma realidade que é apreendida pelas crianças e que nos é comunicada pelo desenho, denotando, na sua semântica, características culturais múltiplas e complexas, umas próprias da geração infância e outras decorrentes das conexões com as outras gerações. 
"E de dentro do circo saiu um passarhomem, metade homem e metade pássaro": as culturas infantis...

\section{Vamos procurar a arquitetura}

Como temos argumentado com os autores de referência, o currículo no jardim de infância resulta de uma interação socioconstrutivista didática que gera conflitos cognitivos nas crianças, provocando, deste modo, a confrontação de ideias que leva à construção do conhecimento, pelo recurso ao desenvolvimento do pensamento apoiado pela linguagem; o pensamento processa-se falando. $\mathrm{Na} \mathrm{Sl}$, o conceito de agência vem reforçar a qualidade das aprendizagens pela participação direta nas ações que às crianças dizem respeito.

Atendendo a que o currículo autoral das crianças é atravessado por propostas exteriores, que chegam à escola vindas da sociedade, por via da autarquia e de outras organizações cívicas ou políticas, as crianças têm a capacidade de as incorporar - entendendo-se que aqui os adultos também fazem parte do grupo e podem influenciar essas entradas -, de as explorar e produzir novos produtos culturais.

O projeto, que agora apresentamos, aconteceu para responder a um desafio da Ordem dos Arquitetos Região Norte, que propunha às escolas participarem numa campanha de sensibilização da arquitetura ao serviço das populações, pelo desafio intitulado "Vamos Procurar a Arquitetura". A proposta foi lançada ao grupo pela educadora, num tempo inicial da manhã, de acolhimento e planificação e "agarrado de imediato" pelas crianças. Seguindo os procedimentos comuns nas rotinas do jardim de infância, inscreveram-se as crianças a quem interessou mais o desafio. Aqui se deu início de imediato a um projeto de investigação que se foi transformando em projeto de intervenção, convocando, para o efeito, o envolvimento de outros agentes sociais - a direção do Agrupamento de Escolas, a Ordem dos Arquitetos, a Câmara Municipal e o Museu Soares dos Reis, para além das famílias que iam acompanhando de perto o desenrolar das fases.

É pelos diálogos e narrativas criadas por estas crianças com os objetos da cultura que as envolvem que conseguimos ir mais além na construção teórica sobre o lugar que ocupam as crianças na sociedade. É pela análise cruzada daquilo que as distingue com o mundo social pensado pelos adultos que conseguimos aprender o que lhes podemos oferecer e enriquecer o nosso currículo de vida.

Com o desafio "Vamos Procurar a Arquitetura", o conceito era novo e indicador de muitas abordagens, desde que as crianças quisessem. Com as que se entusiasmaram, fizemos uma primeira investigação e, mais tarde, abrimos a porta e fomos procurar a arquitetura. As imagens que ficaram nas retinas das crianças, após o que foi visto, constituiu informação suficiente para que as ressignificassem, transmitindo-o para o suporte papel, com a ajuda de materiais de ilustração. Optamos por ir para a rua ver.

As crianças criaram as suas próprias imagens a partir de obras reais de arquitetura e que foram fixadas também pela câmera fotográfica, usada para o efeito, ora pelas próprias crianças ora pela 
educadora. As fotos serviram de apoio à seleção do que pretendiam reproduzir, evocando as experiências visuais vividas, para as suas interpretações do mundo. Assim, nesta atitude de prática cultural escolar, as crianças partiram de um olhar sobre os objetos, usaram imagens desses objetos, construíram outras e foram autoras de uma parte significativamente emocional do seu currículo. As imagens que produziram são fruto da interpretação da realidade sensorial, em tempo direto e dinâmico que passa mensagens e dialoga com as interlocutoras crianças.

Trata-se de um processo de construção de narrativas visuais em primeira mão, isto é, trata-se de uma primeira abordagem feita pelas crianças, diferente do que seria agir sobre uma imagem que Ihes fosse apresentada - matéria a ser discutida nos estudos visuais -, que tem início, meio e fim como se de contar uma história se tratasse. No início, havia a realidade e as imagens dessa realidade (as fotos); no meio, houve lugar à produção de pinturas, representando as obras de arquitetura de que mais gostaram; e no final, a exposição pública no Museu Nacional Soares dos Reis, no Porto, de telas, fotos impressas com os trabalhos das crianças.

As imagens que se seguem, os desenhos das crianças, decorrem dos processos culturais de aprendizagem que se transformaram em objetos simbólicos e, a partir dos quais, testemunhamos a correspondência com artefatos culturais infantis, contextualizados nas condições oferecidas no quotidiano do jardim de infância. Assim, tentamos interpretar cada desenho de forma a garantir a polissemia do artefato cultural, como: produto singular de autor; como artefato social revelador do background cultural de cada criança; como objeto simbólico que apresenta características diversas das de outras gerações. Entender os desenhos como produções simbólicas, à luz da gramática das culturas da infância, exige também, da nossa parte, atender aos meios disponíveis, às rotinas, às práticas institucionais, às relações sociais, à materialidade do gesto gráfico e dos suportes para registro (SARMENTO, 2011: 40), onde os diversos códigos culturais se inscrevem.

\section{I As imagens que pintam as realidades observadas pelas crianças, por elas próprias}

Quais são os elementos distintivos das culturas infantis, no repositório de imagens que a seguir se apresenta? Para responder a esta questão, recorremos à análise visual aos desenhos das crianças. Os desenhos revelam uma apropriação do mundo, particular, através dos conteúdos com que as crianças preenchem o suporte onde fazem as suas composições, e que são de caráter não só plástico, mas também afetivo, cognitivo e cultural. 
"E de dentro do circo saiu um passarhomem, metade homem e metade pássaro": as culturas infantis...

Des. 10 - Ponte de S. Gonçalo

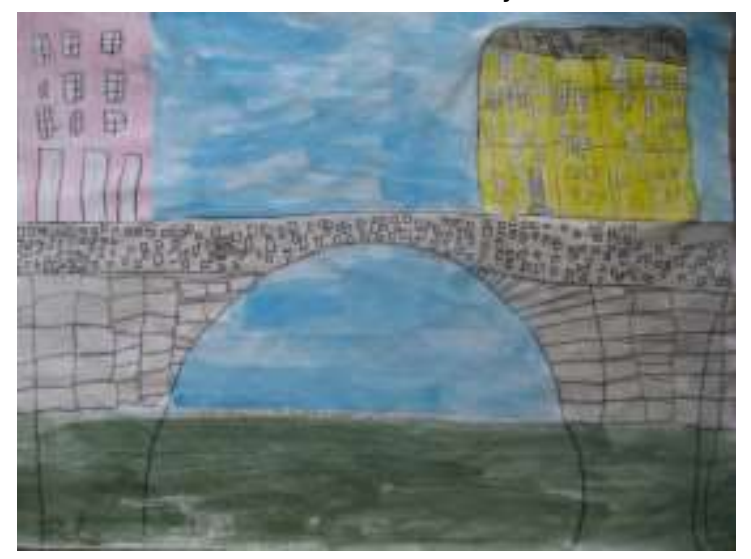

Autora- Rita

Des. 12 - Ponte de S. Gonçalo

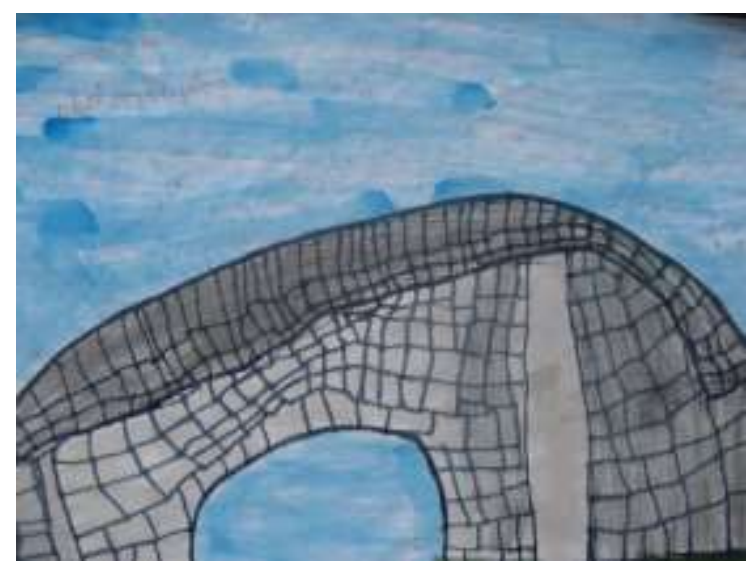

Autor - José Guilherme
Des. II - Ponte de S. Gonçalo

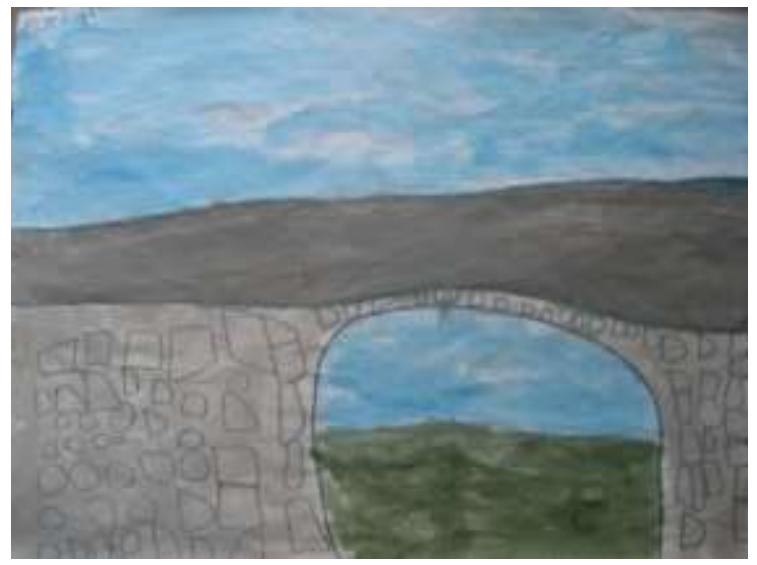

Autora - Matilde

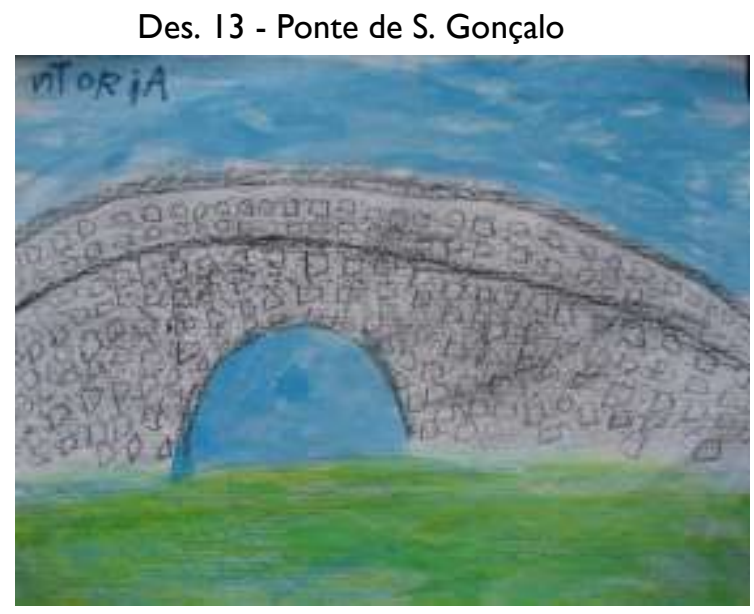

Autora - Vitória

Des. 14 - Ponte de S. Gonçalo

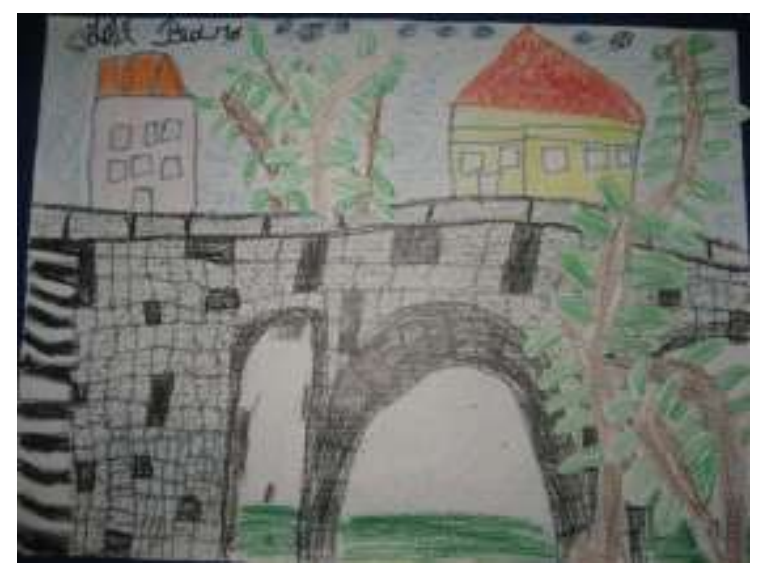

Autor - José Pedro

Olhar de professor, Ponta Grossa, v. 24, p. I-26, e-17619.072, 2021.

Disponível em <https://revistas2.uepg.br/index.php/olhardeprofessor> 
Neste conjunto de 5 desenhos representando o mesmo objeto - a ponte de S. Gonçalo temos cinco interpretações diferentes, ainda que se repitam elementos simbólicos representados do mesmo modo, pela influência do diálogo interpares [identificado por Sarmento como um dos elementos distintivos das culturas infantis], que "[...] permite vislumbrar a emergência de um autor coletivo: as formas e as cores são interpretadas pelos pares" (SARMENTO, 201 I: 49).

No Des. 10, a Rita inseriu os prédios no cenário ao fundo e colocou a água do rio; no plano próximo ocupou toda a área longitudinal da ponte, bem como frisou o seu reflexo, na água; descreveu a estrutura e $\circ$ tabuleiro da ponte com as pedras das paredes e do pavimento; distinguiu a água e $\circ$ céu com cores diferentes.

No Des. II, a Matilde colocou a água apenas debaixo do arco da ponte; viu o céu do outro lado da ponte; registrou a diferença de cores entre o céu e a água; desenhou as pedras dos panos da parede da ponte.

No Des. 12, o José Guilherme focou o seu olhar na ponte, que vale como elemento principal da composição. Regista as duas colunas que ladeiam o arco central e dá força ao conjunto arquitetônico reforçando o contorno das pedras, no conjunto. Água e céu não se distinguem.

No Des. I3, a Vitória ilustra uma ponte com tabuleiro em destaque pelos contornos e com um trabalho meticuloso de representação das pedras da construção. A água está no plano próximo e o céu num segundo plano, em cores diferentes.

No Des. 14, o José Pedro usou materiais diferentes dos anteriores. As outras crianças utilizaram tintas de água, e aqui lápis de cera e lápis de cor. O José Pedro dá-nos outra perspectiva da ponte, com três arcos, e inclui a vegetação à frente e atrás. Representa também os dois edifícios, amarelo e rosa, como a Rita. Destaca algumas das pedras no edifício da ponte e dá relevo à profundidade de dois dos arcos. A ponte ocupa todo o plano próximo e a água ocupa o lugar em baixo, no plano de fundo, com a cor distinta da do céu.

Des. 15 - Mosteiro de Freixo de Baixo

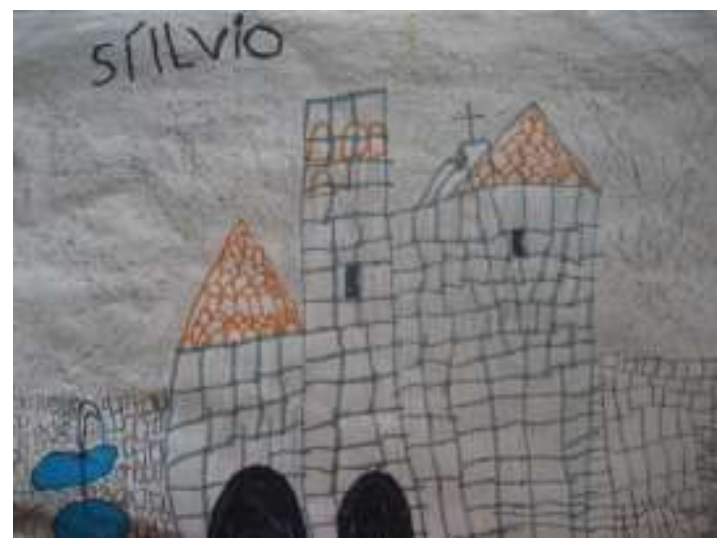

Autor - Sílvio

Olhar de professor, Ponta Grossa, v. 24, p. I-26, e-17619.072, 2021.

Disponível em <https://revistas2.uepg.br/index.php/olhardeprofessor> 
"E de dentro do circo saiu um passarhomem, metade homem e metade pássaro": as culturas infantis...

Des. 16 - Mosteiro de Freixo de Baixo

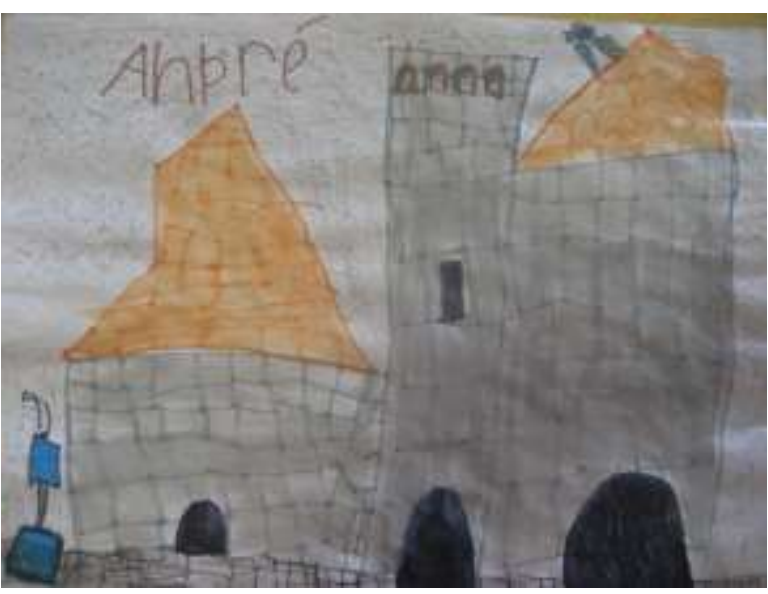

Autor - André
Des. 17 - Mosteiro de Freixo de Baixo

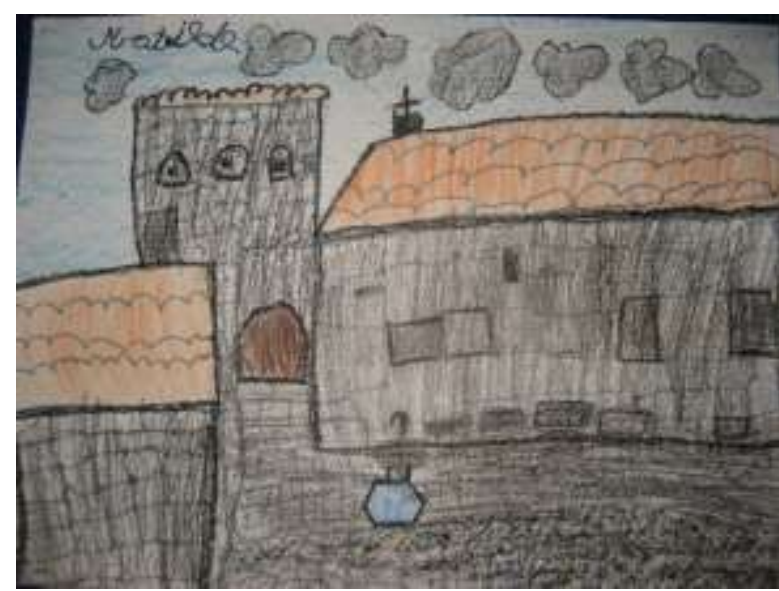

Autora - Matilde P.

Os desenhos 15, 16 e 17 são representações de um mesmo mosteiro. As três crianças dão conta dos vários níveis, das várias peças da construção românica, de diferenças no espaço exterior e de pormenores comuns, como a cruz em cima de um dos telhados e o chafariz, que apesar de ser em granito, é representado pela cor azul. Identificamos aqui um segundo elemento distintivo das culturas infantis - "[...] a criação plástica infantil vive da transação das formas, o plágio não é proibido, antes tolerado e cultivado" (SARMENTO, 20I I: 49).

O Sílvio, com o Des. 15, resolveu o problema dos quatro sinos da torre (que se encontram, na realidade um, em cada um dos quatro lados da torre), adaptando-os ao espaço da sua composição: três em cima e um em baixo. Para a representação das pedras graníticas das paredes, usou um tapete de linhas perpendiculares, e para $\circ$ pavimento pequenas figuras de formato aproximadamente retangular, interpretando os paralelepípedos do chão exterior. A representação das telhas é feita com linhas ondulantes paralelas. O Sílvio viu, neste mosteiro fortaleza, duas portas e duas janelas/seteiras. Todos os elementos se encontram no mesmo plano e num plano próximo.

O André, como o Sílvio, desenhou os telhados em forma triangular correspondendo ao conceito abstrato que têm de telhado e apesar do realismo do objeto modelo (a partir da fotografia do monumento visitado). Incluiu três portas e uma janela/seteira. Usou a técnica das linhas perpendiculares para desenhar as pedras das paredes e colocou em destaque todo o grande corpo do edifício, não deixando quase lugar ao espaço exterior. Os quatro sinos da torre estão plasmados no lado voltado para si.

Denotamos aqui a interatividade e a comunicação entre pares (CORSARO, 2003) e todo o processo de consecução de uma composição gráfica com alicerces no pensamento dialógico das 
crianças - entre o real e a imaginação (VIGOSTSKY, 2008). Este trabalho ficcional corresponde a um terceiro aspeto distintivo das culturas infantis, segundo SARMENTO (20II).

O Des. 17, da autoria da Matilde P., apresenta três edifícios organizados no espaço em três níveis de profundidade. Os telhados são representados com proximidade à realidade, tomando a forma retangular com as telhas desenhadas por linhas ondulantes; os edifícios estão bem destacados do piso, por contornos acentuados. O céu é um elemento enfatizado pela representação de nuvens, de formas arredondadas e contorno ondulado.

Des. 18 - Pormenor Mosteiro de Telões

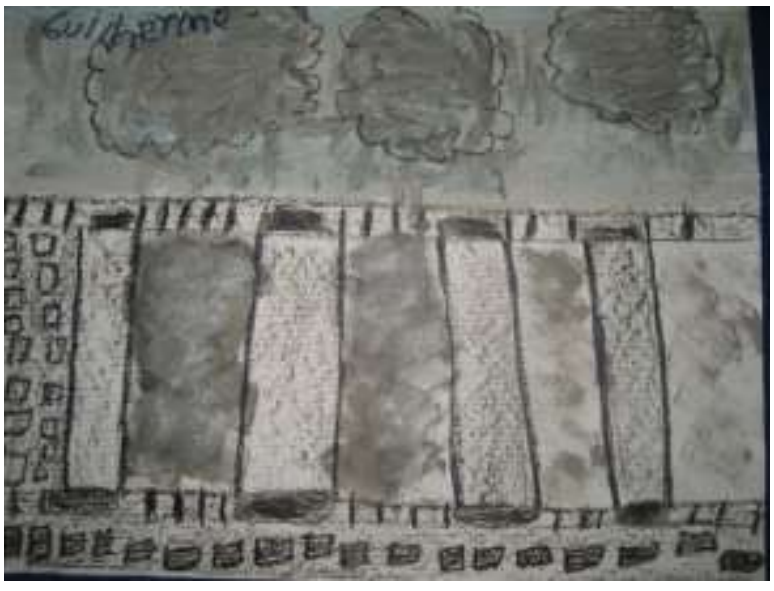

Autor - Guilherme
Des. 19 - Mosteiro de Telões

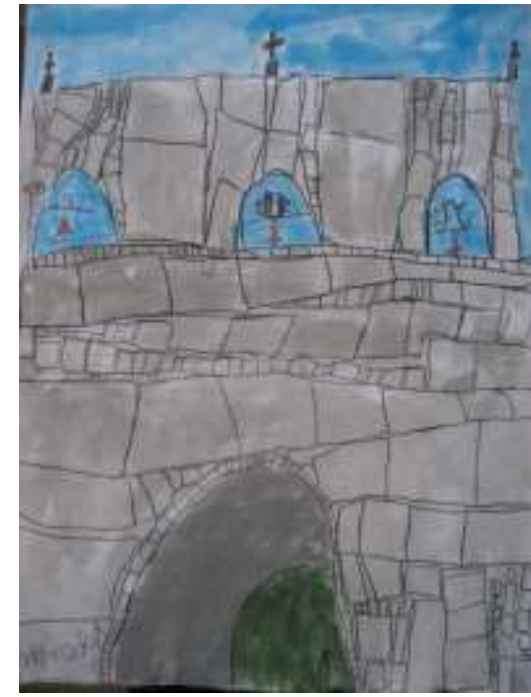

Autor - Salvador

Os desenhos 18 e 19 dizem respeito a um mesmo objeto. Mas enquanto o Guilherme (Des. 18) se dedicou a um pormenor do edifício, numa parede lateral, o Salvador (Des. 19) optou por ilustrar a fachada central. No Des. 18 temos um grande plano de quatro colunas inseridas num pano mural onde estão definidas as pedras de construção. $O$ céu, representado pelas manchas cinzentas de forma arredondada contornadas com ondulação, aproxima-se da cor real do dia chuvoso.

No Des. 19 a torre sineira é apresentada com uma lente de retrato. O Salvador captou pormenores da realidade, como os suportes dos três sinos, a cruz central e as pirâmides que encimam a torre, as diferenças de tamanho dos elementos da construção da parede, a profundidade do arco que dá acesso à porta. O céu do mesmo dia é, aqui, representado pela cor/conceito, tipificado por muitas crianças, de azul. 
"E de dentro do circo saiu um passarhomem, metade homem e metade pássaro": as culturas infantis...

Des. 20 - Igreja de S. Gonçalo

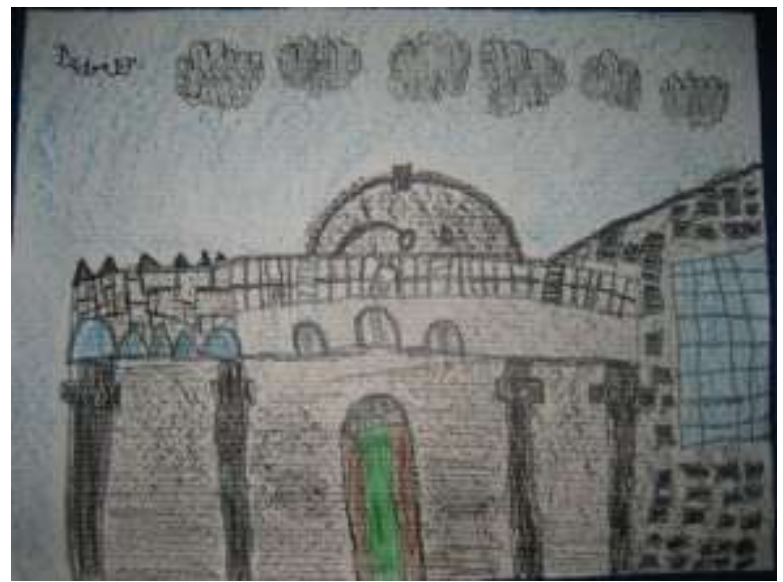

Autor - Pedro
Des. 2 I - Igreja de S. Gonçalo

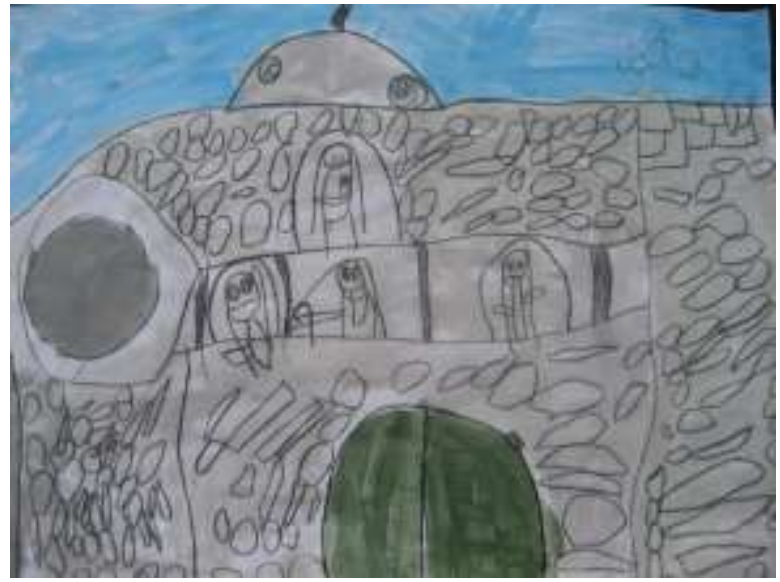

Autor - João

Os desenhos 20 e 21 revelam os olhares do Pedro e do João sobre o mesmo edifício. O Pedro (Des. 20) mostra-nos uma fachada com dois edifícios, onde destaca, à direita, uma grande janela com um painel quadriculado pintado de azul representando a transparência dos vidros e, à esquerda, a complexidade da fachada principal, descrita por elementos de vários tipos: arcos, triângulos, colunas com capiteis em cruz, panos lisos e panos quadriculados. O céu é evidenciado pela representação das nuvens.

O João (Des. 2I) traça, num plano muito aproximado, as linhas principais do conjunto que vê, e preenche-as com formas simbólicas das pedras de construção. Destaca quatro imagens ao centro, em duas linhas sobrepostas - com três figuras em baixo e uma em cima, centrada. $O$ céu é aqui representado pela cor azul que encima a composição.

Des.22 - edifício particular - clínica

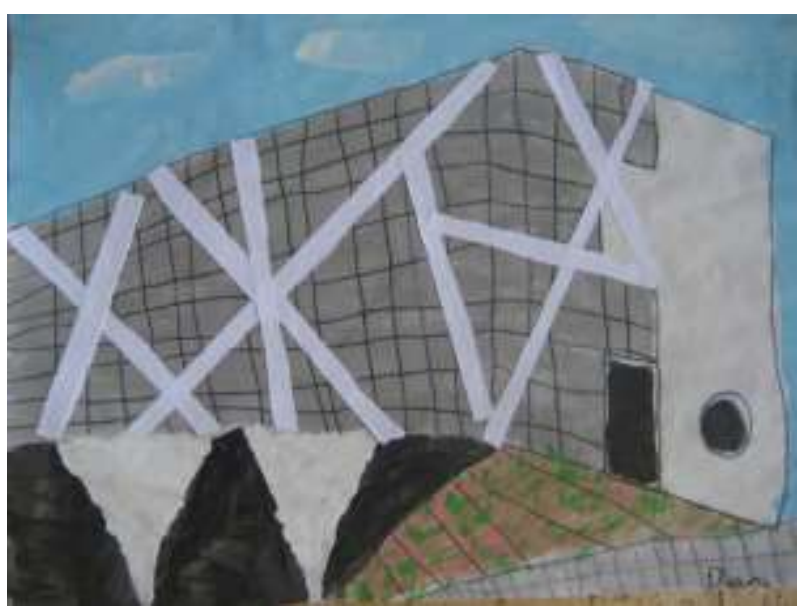

Autora - Diana

Olhar de professor, Ponta Grossa, v. 24, p. I-26, e-17619.072, 2021.

Disponível em <https://revistas2.uepg.br/index.php/olhardeprofessor> 
O Des. 22, da Diana, é uma escolha diversa das outras que correspondem a monumentos. $\mathrm{O}$ edifício é uma construção contemporânea, com muito vidro e aço. A Diana desenhou meticulosas retas e linhas perpendiculares, e nos espaços obtidos pelo cruzamento, pintou de cinza para representar o espelhado dos vidros. As barras de aço são aqui ilustradas por tiras de papel branco coladas sobre o pintado. O espaço exterior - escadas e o espaço de garagem sob o edifício - está também representado nesta composição de técnicas mistas de expressão plástica. $O$ céu é representado pelo fundo pintado de azul e as nuvens são pinceladas brancas como outras crianças também representam.

Os desenhos das crianças vivem de formas que se repetem, como se tudo começasse de novo à semelhança de um jogo ou de uma brincadeira, sendo este mais um traço distintivo das culturas infantis. As crianças, mesmo procurando as semelhanças com a realidade,

[...] inventam formas imaginárias e incorporam elementos fantasistas com sentidos e objetivos muito diversos dessa presumida intencionalidade realista [...]. Tudo se passa como se a criança procure no seu desenho não propriamente representar um real exterior ao desenho, mas, desenhando-o, inscreva como o real da representação, válido em si próprio e interpretável no quadro da polissemia tolerada pelos códigos em que ele foi desenhado (SARMENTO, 20II, p. 39).

Neste conjunto de desenhos, pela sua natureza de interpretação com aproximação ao real, verificamos a reincidência de manifestações da cultura local, da cultura nacional e da cultura de pares, através da similitude dos elementos de representação, mas que não são repetidos do mesmo modo; têm uma origem no coletivo e um desfecho pessoal, tornando as produções todas diferentes e independentes ${ }^{2}$.

Os registros imagéticos, realizados por estas crianças, funcionam para nós - e sob a perspectiva dos estudos da cultura visual - como um texto visual que vai muito além da pura ilustração; que acrescenta novas possibilidades de compreensão dos seus códigos culturais. A divulgação do resultado do projeto integrou a exposição pública no Museu Nacional Soares dos Reis, entre os dias 9 de junho e 3 de julho de 2016.

\section{Amadeo pintor}

O conjunto plástico reunido neste projeto - reproduções de 21 telas de $40 \mathrm{~cm} \times 30 \mathrm{~cm}-$ corresponde à ilustração de um conto, imaginado por um grupo de crianças de 5 anos, após outra visita ao Museu Amadeo de Souza Cardoso. As crianças responderam ao desafio, já no jardim de infância, de criarem uma infância para Amadeo, isto é, construírem a história de Amadeo, antes de ser pintor.

Olhar de professor, Ponta Grossa, v. 24, p. I-26, e-17619.072, 2021.

Disponível em <https://revistas2.uepg.br/index.php/olhardeprofessor> 
"E de dentro do circo saiu um passarhomem, metade homem e metade pássaro": as culturas infantis...

A partir do observado no museu, das obras do pintor e da interpretação do discurso da pessoa que orientou a visita guiada, uma vez já na sala de atividades, as crianças recrearam oralmente acontecimentos verídicos e, espicaçadas por conectores de tempo, outros espaços, outras personagens, deram-lhe uma roupagem de fantasia, criaram a sua própria narrativa em grupo, para um Amadeo menino que nasceu como todos os meninos e viveu observando e pintando - na versão das crianças.

À medida que as crianças se expressavam e que se ia evoluindo na construção do diálogo de grupo, as educadoras (e investigadora) que interagiam, iam secretariando também as falas. Depois da história concluída, a proposta foi, como acontece com outras histórias, que se ilustrasse. Num primeiro momento, cada criança desenhou sobre a parte do texto o que mais lhe agradou; depois, conferindo o que havia necessidade de dar visibilidade e que ainda não a tinha, constituíram-se grupos de pares para terminar a tarefa da ilustração.

Por último, fotografaram-se as produções e imprimiram-se nas telas, cujo registro deixamos a seguir. As legendas constituem o corpo do texto dito pelas crianças.

Des. 23 - Pintura coletiva, de crianças de 3 anos, com escrita de criança de 5 anos, que abre a obra cultural infantil "Amadeo Pintor"

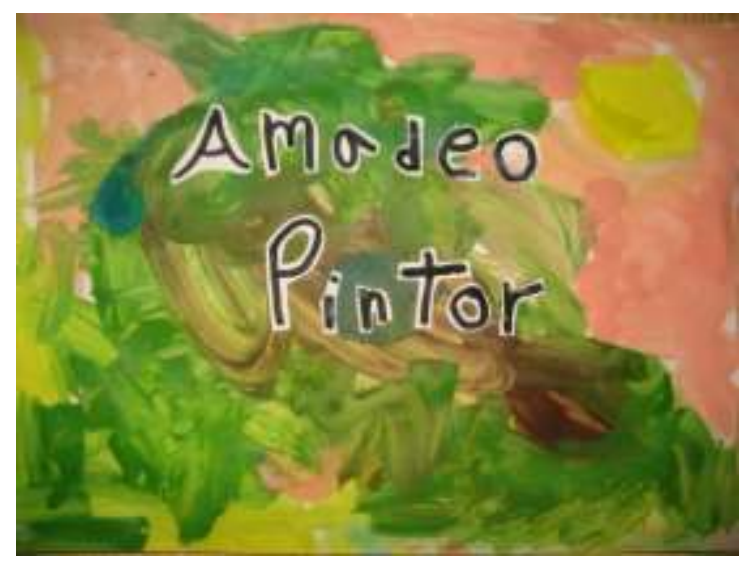

Autores: coletivo
Des. 24 - "Era uma vez..

Um menino que se chamava Amadeo. Nasceu na barriga da mãe. Quando estava dentro da barriga, a mãe levava-o a passear a pé, a ver as árvores, a ver os frutos a nascer".

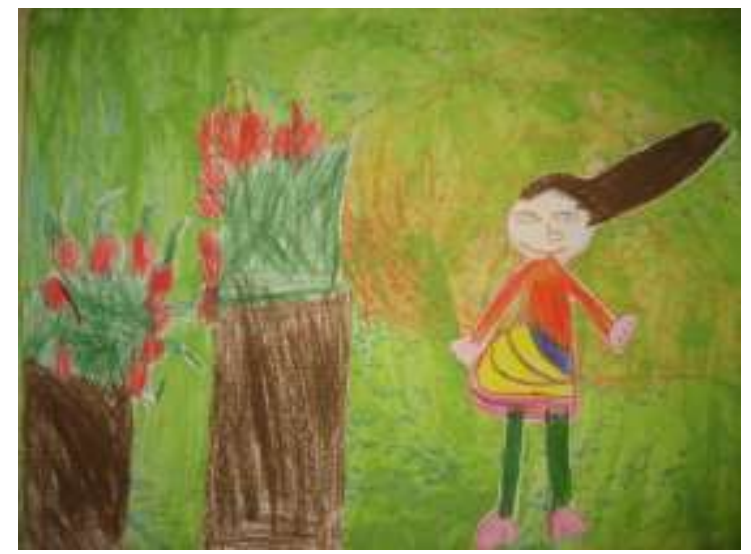

Autores: Joana e Martim 
Des. 25 - "Num desses passeios a mãe sentiu ele a nascer e foi para o hospital a correr, muito depressa e preocupada. Foi acelerada!"

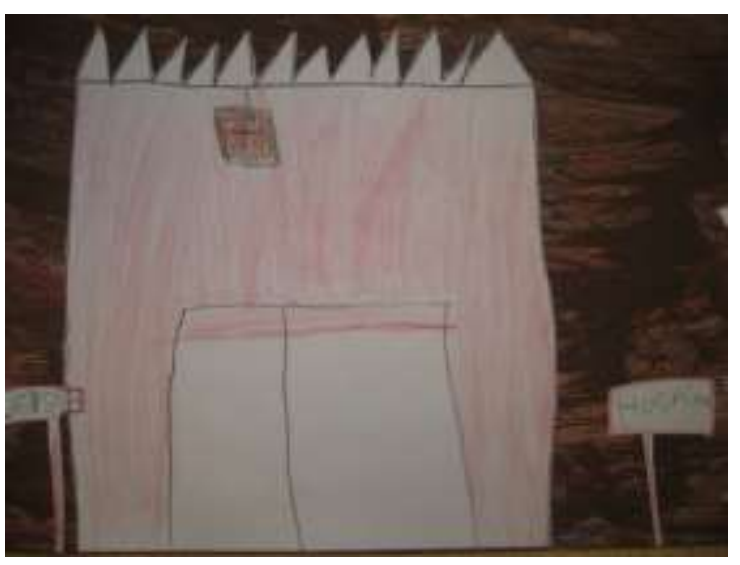

Autor: Santiago

Des. 27 - "De repente, nasceu! E depois cresceu. E a mãe foi passear com ele ao parque. Lá, encontrou outro menino que se chamava Martim. Perguntoulhe: queres brincar comigo? E ele quis."

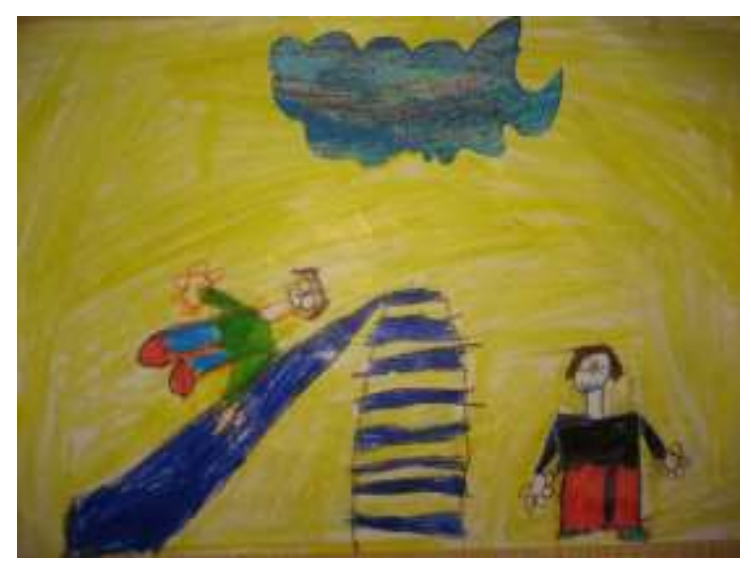

Autor - Tomás
Des. 26 - "O táxi andava muito depressa, as rodas rodavam muito rápido e o bebé sentia-se a andar às voltas dentro da barriga da mãe. De repente nasceu!"

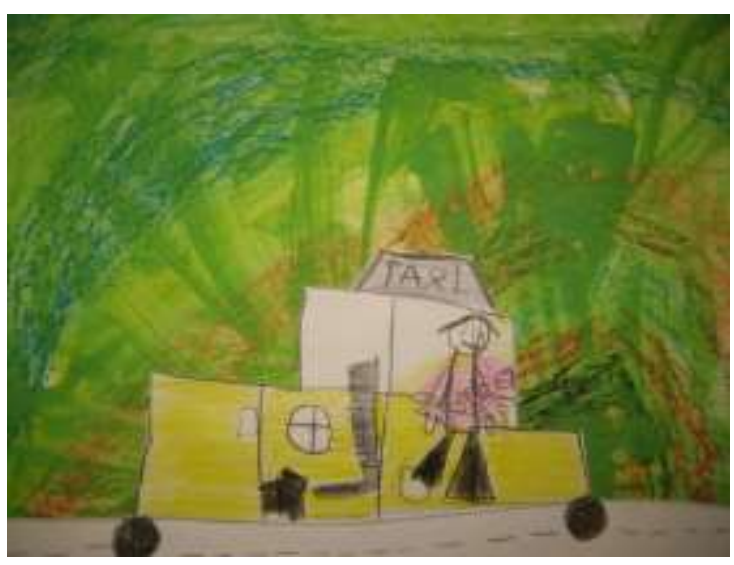

Autor: Santiago

Des. 28 - "Quando foram embora, eles viram uma taça de ouro, dentro de uma caixa, fechada, à beira da estrada. Conseguiram descobrir o código, abriram a caixa e quando iam a pegar na taça de ouro ... ela desfez-se."

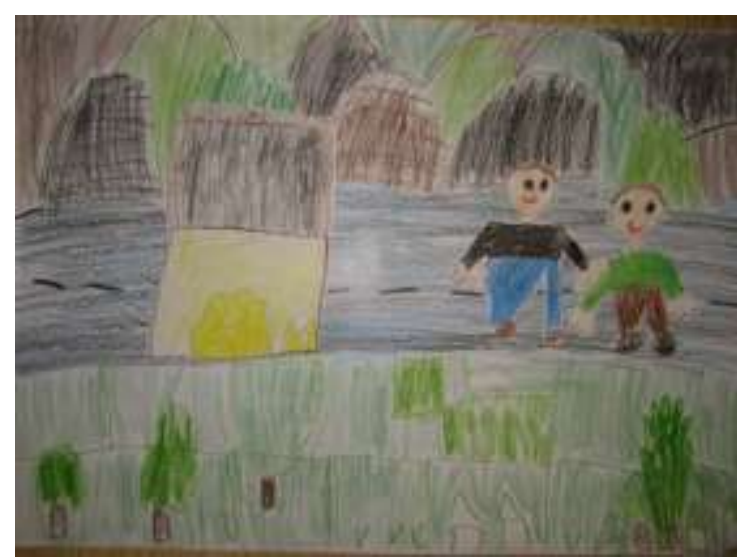

Autor: Dário 
"E de dentro do circo saiu um passarhomem, metade homem e metade pássaro": as culturas infantis...

Des. 29 - "Eles ficaram muito aflitos e queriam colá-la para ela ficar inteira outra vez, mas não conseguiam. Então, ficaram muito espantados porque de lá de dentro saiu um circo!”

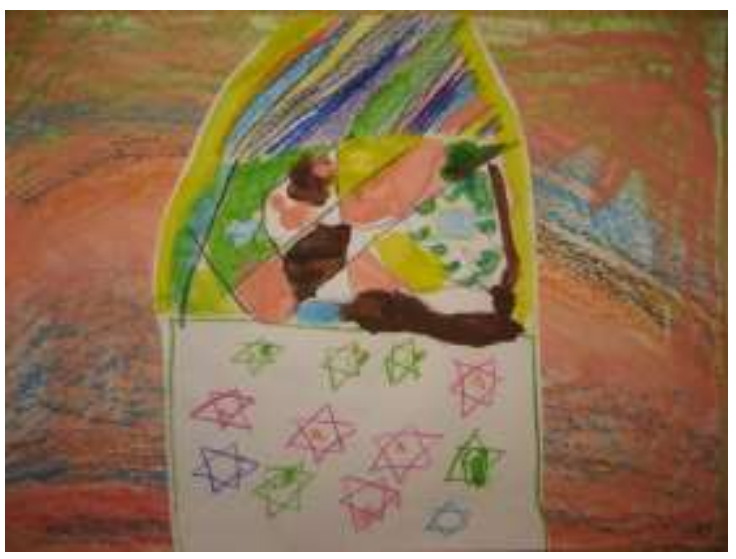

Autores: Margarida e Joana

Des. 31 - "Pegou nos meninos, um em cada asa, e levou-os a voar pelo céu."

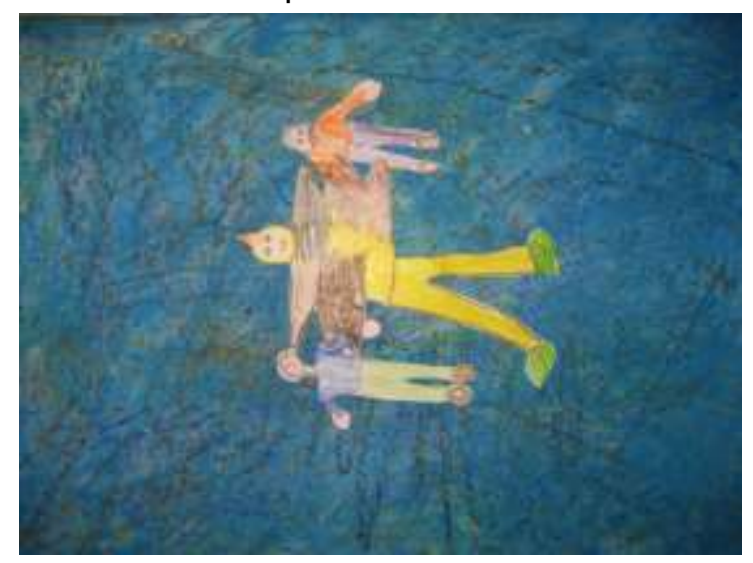

Autores: Vasco, Joana e Tomás

Des. 33 - "homens a tocar viola e violino..."

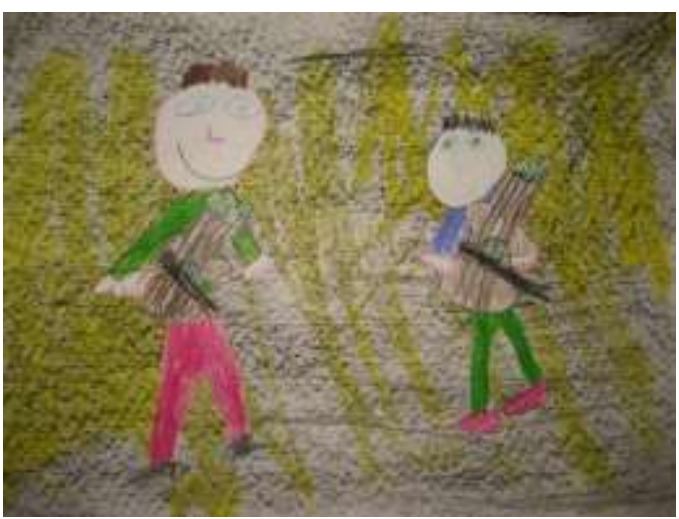

Autores: Adriana e Leonor T.
Des. 30 - "E de dentro do circo ... apareceu lá um passarhomem - que é um homem que é metade homem e metade pássaro!'

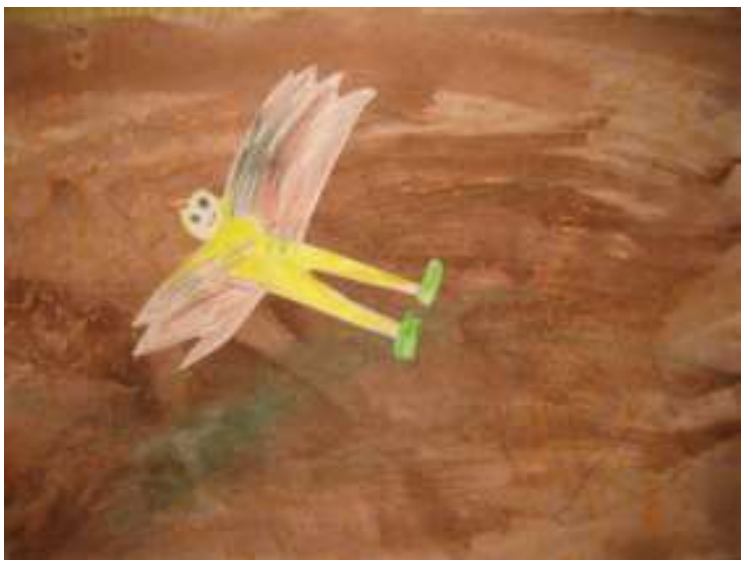

Autores: Vasco e Joana

Des. 32 - "Viram outros pássaros..."

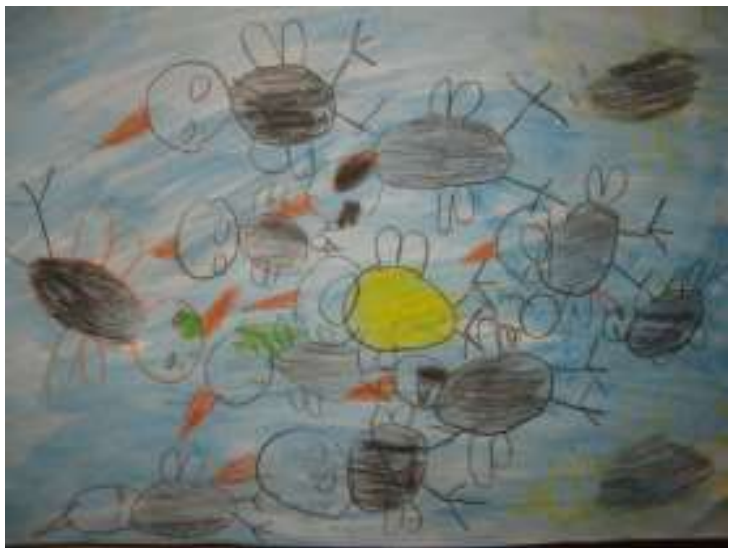

Autor: Santiago

Des. 34 - "casas no meio das montanhas..."

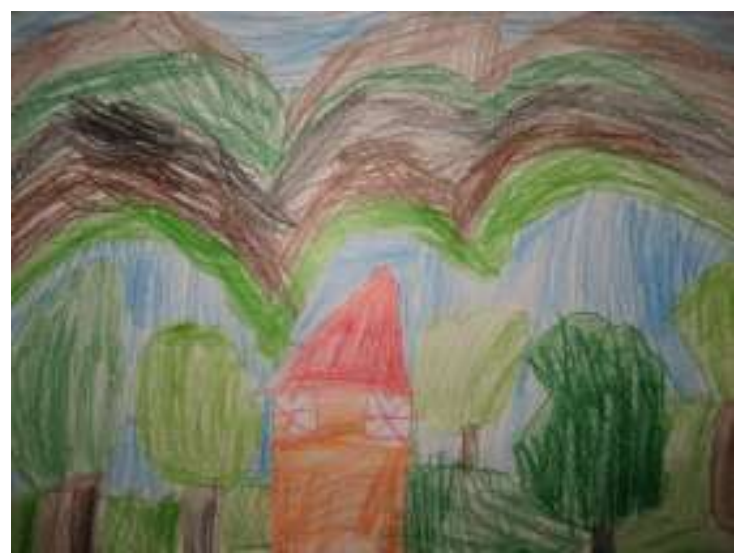

Autora: Tânia

Olhar de professor, Ponta Grossa, v. 24, p. I-26, e-176|9.072, 2021.

Disponível em <https://revistas2.uepg.br/index.php/olhardeprofessor> 
Des. 35 - "umas árvores gigantes que tinham lá dentro esquilos."

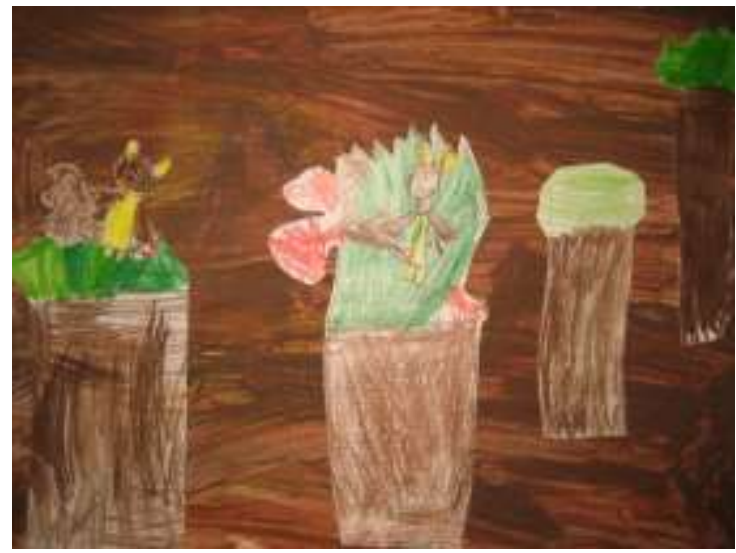

Autor: Dário

Des. 37 - "Mas era um circo especial: não tinha palhaços nem animais; era quadrado, tinha quadros, tinha pessoas a pintar quadros em forma de coração, em forma de círculo, em forma de triângulo."

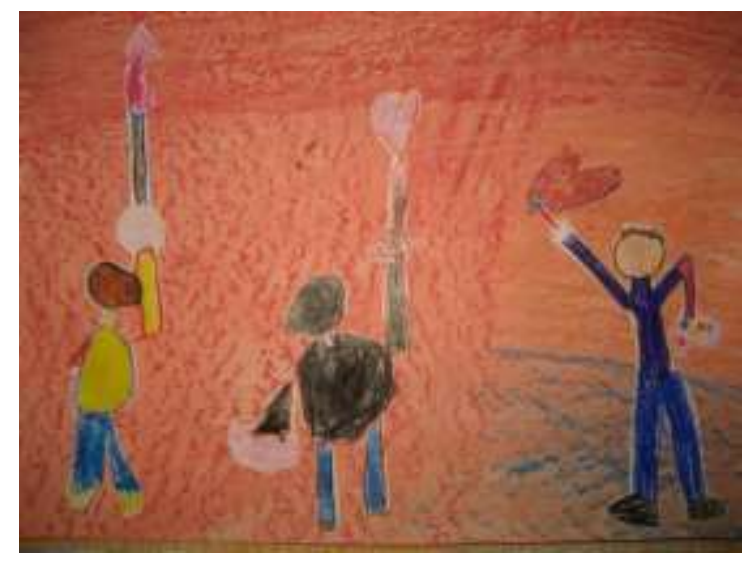

Autora: Joana M. e Joana
Des. 36 "O passarhomem levou-os até ao circo."

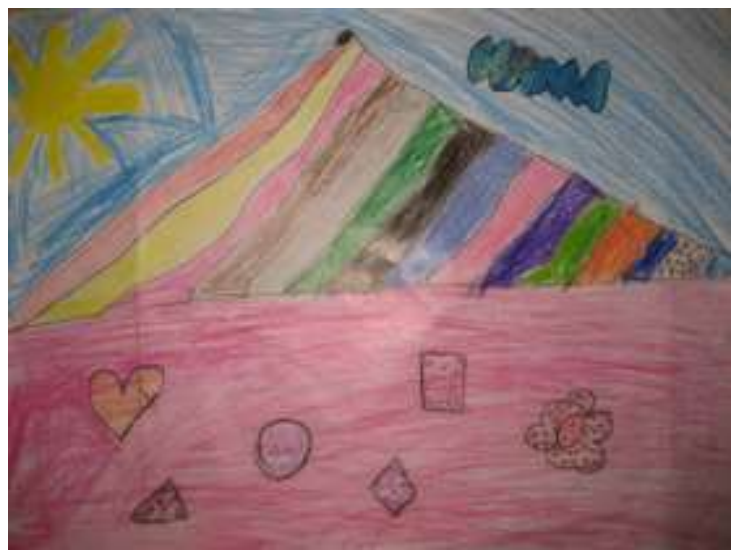

Autora: Leonor T.

Des. 38 - "O Amadeo e o amigo ficaram espantados! Parecia que estavam dentro de um sonho. De repente, viram uma luz a apontar para eles. E apagou-se! Ficou tudo escuro."

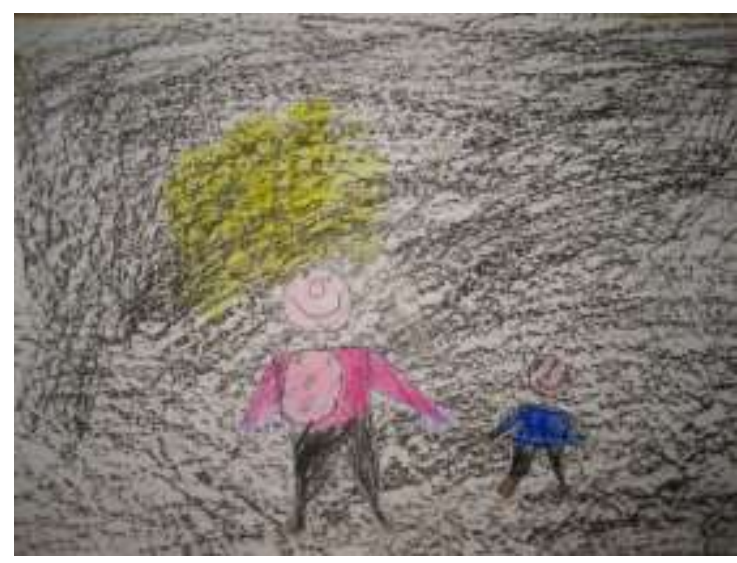

Autores: Dário e Tomás 
"E de dentro do circo saiu um passarhomem, metade homem e metade pássaro": as culturas infantis...

Des. 39 - "O Amadeo calcou qualquer coisa: era uma tinta. A tinta abriu-se, ele pensava que era... mas não era: saíram de lá duas tiaras!"

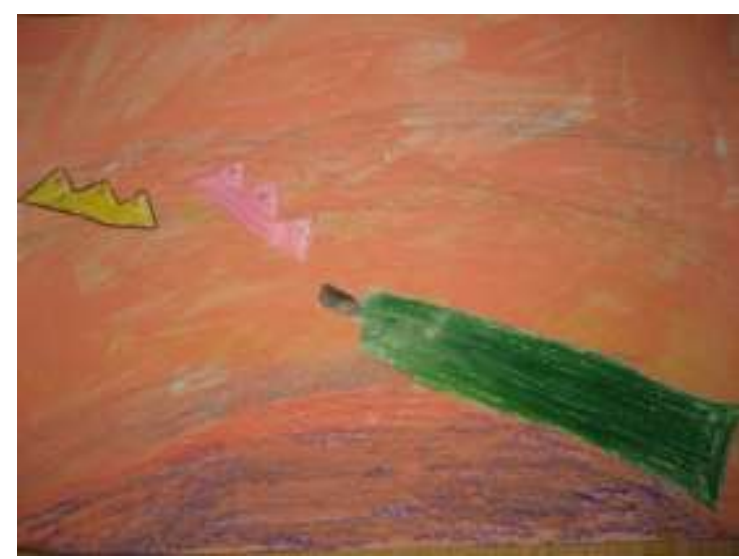

Autores: Joana, Adriana, Martim

Des. 4I - "Estava lá a mãe e ele ofereceu-lhe a tiara."

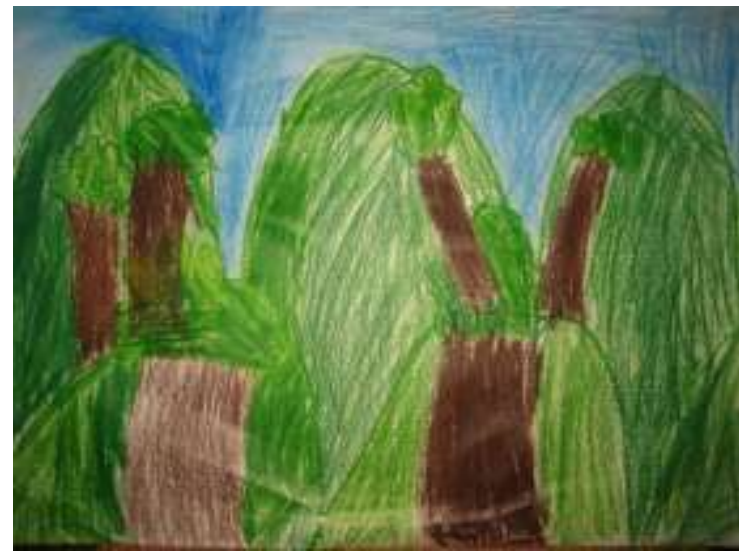

Autora: Joana
Des. 40 - "Pediram ao passahromem para ir ter com as mães. Ele levou-os até uma casa que parecia um castelo - era a casa de Manhufe."

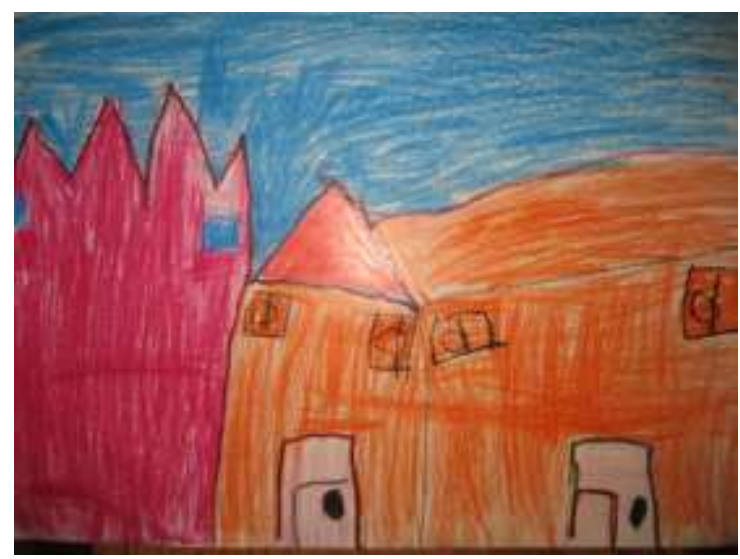

Autora: Leonor S.

Des. 42 - "O Amadeo subiu as escadas, foi para cima da torre e de lá via os campos... e tudo!

- Ah! - Quero ficar aqui a pintar tudo... até ao

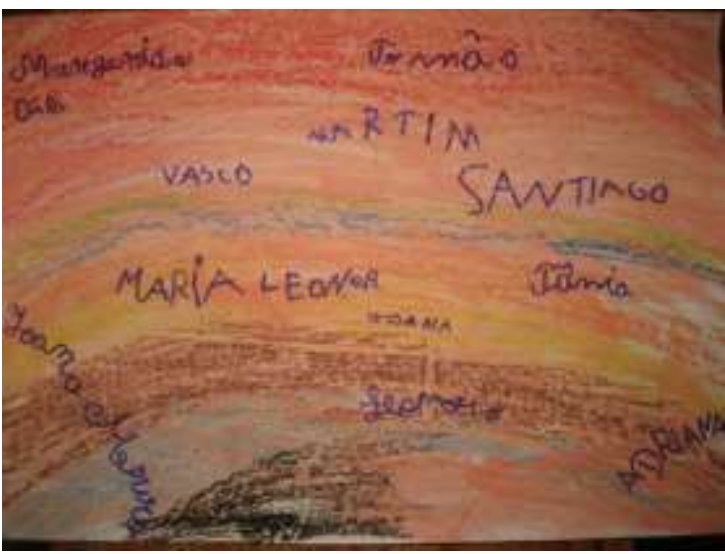

Autor: Tomás 
Des. 43 - "Perlimpimpim a história chegou ao fim!"

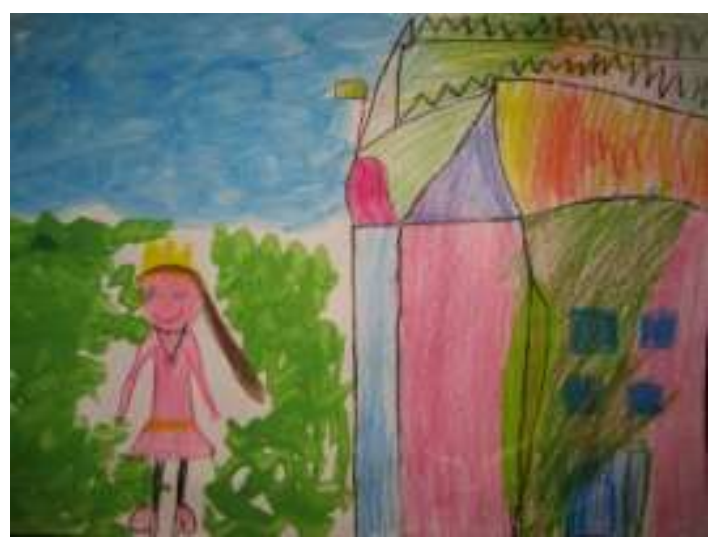

Autoria coletiva

São recorrentes, na criação de histórias, as expressões que marcam o início e o fim (Des. 43). Não foram as crianças que as inventaram, mas apropriam-se delas, reutilizam-nas e transmitem-nas oralmente. Quanto à forma, ela não obedece a um padrão, mas descobre-se um fio condutor sugerido pelos elementos que as crianças, com os seus saberes, escolhem para dar corpo ao conteúdo. Aqui, são visíveis: i) as informações recolhidas no museu sobre o artista (Des. 33; 34; 40), a sua obra (Des. 37) e a sua casa (Des. 40) - da cultura nacional; ii) a utilização de variáveis do quotidiano do jardim de infância, como o nome do menino (Des.27), a referência ao circo (Des. 29) que aporta com frequência à localidade (e traz crianças que vêm frequentar este jardim de infância), e conceitos matemáticos - da cultura escolar; iii) a integração de elementos naturais e práticas de tempos livres com a família - cultura local; iv) a criação de um neologismo - o 'passarhomem' (Des. 30) e o recurso à magia, para responder à necessidade intrínseca da fantasia infantil e resolver problemas. A ludicidade e a fantasia, os afetos (Des. 3I; 36; 37; 38; 39), a impressão deixada pelo contacto com a obra do artista/pintor local, a evocação dos pares, são características dominantes neste artefato de cultura infantil. A familiaridade destas crianças com o meio rural - descrito e ilustrado pelas árvores, animais, circo -, com a proximidade ao meio urbano - taxi, hospital -, com a obra de Amadeo - descrição do interior do circo-museu, com pintores, quadros de formas geométricas (como Amadeo gostava de fazer), tinta e a integração da sua residência de Manhufe -, e as conexões estabelecidas com a fantasia, dão rosto a uma obra inédita de cultura infantil.

Esta obra de cultura infantil foi divulgada em exposição pública, na Câmara Municipal, quando das festas da cidade e integrando a sua programação. Do convite para o evento e do livro de visitas, ficam as imagens: 
"E de dentro do circo saiu um passarhomem, metade homem e metade pássaro": as culturas infantis...

Des. 44 - Convite exposição 'Amadeo Pintor'

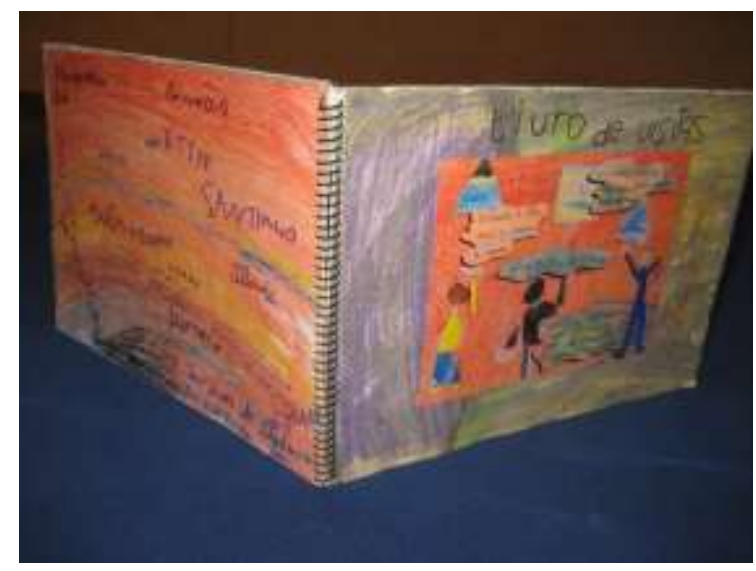

Fonte: autora
Des. 45 - Livro de visitas da exposição Amadeo

Pintor

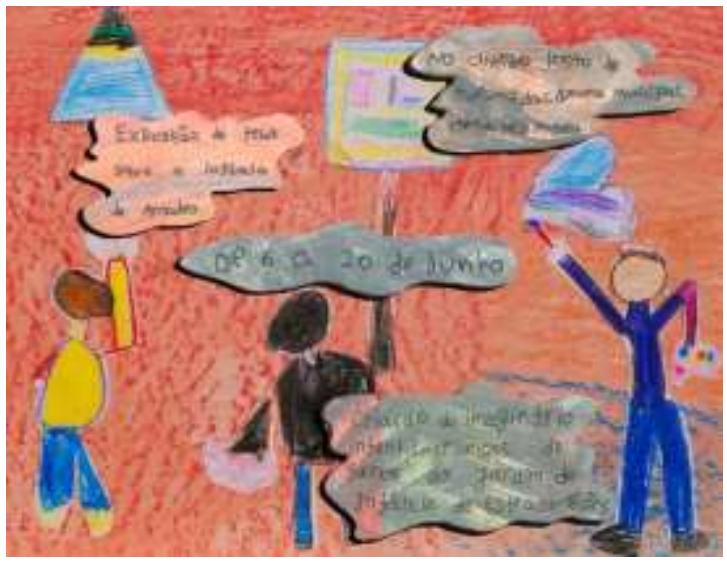

Fonte: autora

\section{Em síntese}

O conceito de culturas infantis aqui é central, pois ajuda-nos a perceber a capacidade de as crianças produzirem elementos culturais próprios e de como participam na cultura global, a partir das vivências próximas. As crianças são geralmente influenciadas pelas relações interpessoais que mantêm com um círculo de contactos e um meio próximos (família, amigos, vizinhos, professores...) que as catapulta, e reproduzem essas interações nas suas formas de expressão artística, ou, como afirma Malchiodi:

As imagens das crianças, sobre a vizinhança, sobre a escola e a comunidade podem ser consideradas reflexos delas próprias, mas também são imagens do que as crianças veem, sentem, experienciam, e pensam acerca das outras pessoas e do meio. Apesar dos aspetos interpessoais dos desenhos das crianças poderem ser vistos como parte do conteúdo emocional do seu trabalho criativo, estes aspetos também refletem o olhar do eu em relação aos outros e a realidade é de ter em conta numa perspetiva interpessoal (MALCHIODI, 1998, p. 16I).

Possibilitar a expressão e a exploração das ideias das crianças, pelo desenho ou outras formas artísticas de representação, é um direito que lhes assiste enquanto ferramenta para o desenvolvimento de competências múltiplas no processo do conhecimento e do crescimento pessoal.

Os desenhos, as construções plásticas das crianças e a voz que lhes dão são importantes formas de expressão simbólica, que revelam particularidades dos contextos em que estão inseridas e desconstroem a ideia normalizadora que a sociedade, por vezes, Ihes quer atribuir, abstratamente (SARMENTO, 20II).

Nas suas representações do mundo, as crianças mergulham no imaginário que thes dá a possibilidade de repetir e reinventar a vida, num determinado menu que lhes é sugerido pelo contexto. 
Com os diversos ingredientes colhidos dos vários tipos de socialização envolventes - cultura familiar, cultura nacional, cultura global, cultura escolar, cultura de pares - as crianças elaboram ementas autorais: artefatos de cultura infantil, distantes da gramática adultocêntrica de cultura para a infância. O tratado dos factos e das leis que regem a cultura, do ponto de vista dos adultos, é substancialmente diferente de uma gramática da fantasia das crianças.

\section{Referências}

ALANEN, L. Childhood as a social phenomenon: national report. Viena: European Center, 1990.

BARBOSA, M. C.. Revista Educação e Sociedade, v.80, n. I00, p. I059-I 083, 2007.

CORSARO, W. A. We're friends, right? Inside kids culture. Washington: Joseph Henry Press, 2003.

CORSARO, W. A. Sociologia da infância. Porto Alegre: Artmed, 201 I.

FERNANDES, N.; TOMÁS, C. Participação e ação pedagógica: a valorização da competência e ação social das crianças. In: CONGRESSO INTERNACIONAL GALEGO-PORTUGUÊS DE PSICOPEDAGOGIA, 10., 2009 Atas [...]. Braga: Universidade do Minho, 2009.

HALLDÈN, G. The Metaphors of Childhood in a Preschool Context. Parer presented at AARE Conference, Sidney, 2005.

PROUT, A. Reconsiderando a nova sociologia da infância. Cadernos de Pesquisa, v. 40, n. I4I, p.729-750, 2010.

PROUT, A.; JAMES, A. Constructing and reconstructing Childhood. London: The Falmer Press, 1990.

QVORTRUP, J. O. O trabalho escolar infantil tem valor?: a colonização das crianças pelo trabalho escolar. In: CASTRO, L. R. (Org.). Crianças e jovens na construção da cultura. Rio de Janeiro: NAU; FAPERJ, $200 \mathrm{I}$.

SARMENTO, M. J. A reinvenção do ofício de criança e de aluno. Atos de pesquisa em educação, v.6, n.3, p.58I-60, $200 \mathrm{I}$.

SACRISTÀN, S. J. O Aluno como Invenção. Porto: Porto Editora, 2006.

SARMENTO, M. J. As Culturas da infância nas encruzilhadas da $2^{a}$ modernidade. In: SARMENTO, M. J.; CERISARA, A. B. (Coord.). Crianças e Miúdos: Perspectivas sociopedagógicas sobre infância e educação. Porto: Asa, 2004. p.9-34.

SARMENTO, M. J. Conhecer a infância: os desenhos das crianças como produções simbólicas. In: FILHO, A. J. M.; PRADO, P. D. (Orgs.). Das pesquisas com crianças à complexidade da infância Campinas, SP: Autores Associados, 20I I. p. 27-60.

Olhar de professor, Ponta Grossa, v. 24, p. I-26, e-17619.072, 2021.

Disponível em <https://revistas2.uepg.br/index.php/olhardeprofessor> 
SARMENTO, M. J. A sociologia da infância e a sociedade contemporânea. In: ENS, R. T.;

GARANHANI, M. C. A sociologia da infância e a formação de professores. Curitiba: Champagnat, 2013.

SOARES, N. F.; SARMENTO, M. I.; TOMÁS, C. A. Investigação da infância e crianças como investigadoras: metodologias participativas dos mundos sociais das crianças. Nuances:

Estudos sobre Educação UNESP, Presidente Prudente, v. I2, n. I3, p. 49-64, 2005. DOI: https://doi.org/I0.14572/nuances.vI 2il3.1678

TISDALL, E. K. M.; DAVIS, J. M.; HILL, M.; PROUT, A. (Eds.). Children, Young People and Social Inclusion: Participation for what? Bristol: The Policy Press, 2006.

VIGOTSKY, L. A formação social da mente. São Paulo: Martins Fontes, 2008.

Recebido em: 13 de março de 2021 .

Versão corrigida recebida em: 14 de junho de 2021 .

Aceito em: 14 de junho de 202I.

Publicado online em: 17 de julho de 2021 . 